\title{
Transcriptome analysis of the fish pathogen Flavobacterium columnare in biofilm suggests calcium role in pathogenesis
}

\author{
Wenlong Cai ${ }^{1}$, Leonardo De La Fuente ${ }^{2}$ and Covadonga R. Arias ${ }^{1 *}$ (D)
}

\begin{abstract}
Background: Flavobacterium columnare is the causative agent of columnaris disease that affects cultured freshwater fishes worldwide. F. columnare easily colonizes surfaces by forming biofilm, which helps the pathogen resist antibiotic and disinfectant treatments. Previously, we had shown that increasing concentrations of calcium $\left(\mathrm{Ca}^{2+}\right)$ promoted biofilm formation by F. columnare. The objective of this study was to further characterize the role of $\mathrm{Ca}^{2+}$ on biofilm formation and to compare the transcriptome profiles of planktonic and biofilm cells.

Results: RNA-Seq analysis was conducted to identify genes that were differentially expressed between the following states: i) planktonic cells in control medium (P), ii) planktonic cells in calcium-enriched medium (P/Ca), and iii) biofilm cells in calcium-enriched medium (B/Ca). Overall, we identified 441 significant (FDR-adjusted $p<0.05$, fold change $>2$ ) differentially expressed genes (DEGs) between $\mathrm{P}$ and $\mathrm{B} / \mathrm{Ca}$ samples; 112 significant DEGs between P/Ca and B/Ca samples, and 175 significant DEGs between P/Ca and P samples, corresponding to 15.87, 4.03 and $6.30 \%$ of the total protein-coding sequences, respectively. The significant DEGs fell into different functional categories including iron acquisition, oxidative stress response, extracellular protein secretion, and respiratory metabolism.
\end{abstract}

Conclusions: Our results posit $\mathrm{Ca}^{2+}$ as a critical signal in regulating bacterial surface adhesion and biofilm formation in F. columnare. Living in biofilm elicited a shift in several metabolic pathways that allowed the cells to cope with oxidative stress and nutrient starvation. In addition, $\mathrm{Ca}^{2+}$ supplementation induced the expression of putative virulence factors in F. columnare, such as extracellular protein secretion and iron acquisition.

Keywords: Flavobacterium columnare, Biofilm, Calcium, RNA-seq, Water hardness

\section{Background}

Flavobacterium columnare is a Gram negative bacterium that is the causative agent of columnaris disease in fish. This bacterial fish pathogen causes great economic losses in key aquaculture species worldwide such as channel catfish, tilapia, and trout [1]. Flavobacterium columnare is considered to be ubiquitous in freshwater environments including fish farms. Recurrent columnaris outbreaks are common in farms and eradication is extremely difficult. Columnaris disease is transmitted horizontally by fish-to-fish contact and asymptomatic fish can easily vector the pathogen into a farm. Although

\footnotetext{
* Correspondence: ariascr@auburn.edu

${ }^{1}$ School of Fisheries, Aquaculture, and Aquatic Sciences, Auburn University,

203 Swingle Hall, Auburn, AL 36849, USA

Full list of author information is available at the end of the article
}

columnaris disease can be transmitted through water, cell counts of $F$. columnare in water are typically very low, even during active outbreaks [2]. Once fish are removed from a system, F. columnare quickly disappears from the water column suggesting that, in the aquatic environment, the planktonic state of $F$. columnare is transient [2]. Conversely, F. columnare colonizes natural and manmade materials quickly and remains viable, and infective, in biofilms even when fish host are not available [3].

Biofilms can be defined as bacterial communities that are attached to solid surface and covered with exopolysaccharides. Living in a biofilm offers aquatic bacteria many advantages over the alternative planktonic stage including a better adaptation to nutrient deprivation, and increased resistance to stressors such as desiccation

(c) The Author(s). 2019 Open Access This article is distributed under the terms of the Creative Commons Attribution 4.0 International License (http://creativecommons.org/licenses/by/4.0/), which permits unrestricted use, distribution, and 
and antimicrobial compounds [4]. Biofilm development requires several key steps, i.e., transport and attachment of planktonic bacteria onto a surface, cell proliferation, formation of microcolonies, and dispersion of daughter cells into the water column [5]. In vivo studies by Straus et al. (2015) demonstrated that higher calcium $\left(\mathrm{Ca}^{2+}\right)$ concentrations in rearing tanks water increased $F$. columnare attachment to gills and subsequent host colonization [6]. Columnaris disease is primarily an epithelial disease that causes necrotic skin and gill lesions [1]. As F. columnare colonizes the host, whitish plaques often appear along the fish body that exhibit yellow borders due to the masses of pigmented $F$. columnare. In a sense, columnaris disease can be considered a biofilm infection that invades the fish from the outside in [7]. Previous studies have shown that $\mathrm{Ca}^{2+}$ promotes binding to surfaces and biofilm formation by $F$. columnare $[3,8]$ and appears to enhance virulence in fish, however, the mechanisms by which calcium regulates these processes are unknown.

The objectives of this study were: i) to elucidate the differential transcriptional regulation between planktonic and biofilm states of growth, and ii) to determine the effect of $\mathrm{Ca}^{2+}$ in the transcriptional regulation of planktonic cells. This transcriptional analysis increased our understanding of the effect of environmental stimuli $\left(\mathrm{Ca}^{2+}\right)$ and subsequent cell responses that drive successful biofilm colonization.

\section{Results}

Biofilm formation under increased $\left[\mathrm{Ca}^{2+}\right]$

Calcium supplementation promoted biofilm formation by $F$. columnare on the wall of flasks. Without $\mathrm{Ca}^{2+}$ supplementation, F. columnare cells remained planktonic and there was no observable biofilm in the flasks (Fig. 1) . For this reason, we were not able to obtain enough
RNA for whole transcriptome analysis of biofilms growing in control medium. At the other end of the spectrum, at $6.5 \mathrm{mM}\left[\mathrm{Ca}^{2+}\right]$, cells grew in large clusters that quickly precipitated to the bottom after shaking ceased and there was no visible biofilm on the glass walls. Moreover, at $6.5 \mathrm{mM}\left[\mathrm{Ca}^{2+}\right]$, there was no turbidity in the medium due to the absence of planktonic cells. Based on those observations, $4.5 \mathrm{mM}$ $\left[\mathrm{Ca}^{2+}\right]$ was deemed as the best concentration to use for RNA-Seq analysis since it produced sufficient biofilm on the walls of the flask while enough planktonic cells remained in culture.

\section{Quantitative analysis of global gene expression}

The mapped reads, using $F$. columnare $94-081$ as reference genome, ranged from $12.5 \mathrm{M}$ to $22 \mathrm{M}$ with an average of $15.4 \mathrm{M}$ per sample (Additional file 2: Figure S1). Principal component analysis (PCA) was performed on the raw RNA-seq reads that mapped to the reference genome to evaluate repeatability. The PCA plots showed that the biological replicates were well aggregated (Fig. 2) . On PC1, there was a clear differentiation between the transcripts in planktonic cells with and without calcium amendment, while the differentiation between the biofilm cells under calcium amendment and planktonic cells under calcium amendment was observed on PC2.

Figure 3 plots genes exhibiting significant expression changes (fold change $\geq 2$; FDR-adjusted $p<0.05$ ) among the three pair-wise comparison groups. Overall, we identified 175 DEGs (135 upregulated, 40 downregulated) between planktonic-control (P) and planktonic- $4.5 \mathrm{mM}$ calcium (P/Ca) groups (Fig. 3a); 112 DEGs (61 upregulated, 51 downregulated) between $\mathrm{P} / \mathrm{Ca}$ and biofilm-4.5 $\mathrm{mM}$ calcium (B/Ca) groups (Fig. 3b), and 441 DEGs (286 upregulated, 155 downregulated) between $\mathrm{P}$ and $\mathrm{B} /$ Ca groups (Fig. 3c). These genes represent 6.30, 4.03,

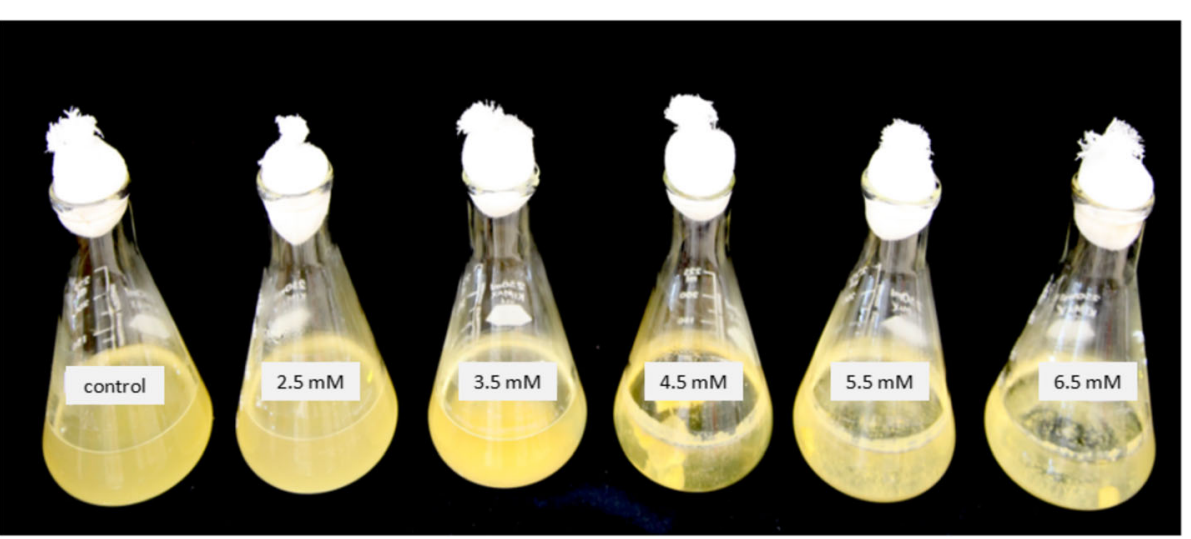

Fig. 1 Biofilm formation of F. columnare in Erlenmeyer flasks after $48 \mathrm{~h}$ inoculation under different calcium concentrations. Visually, there was a positive correlation between $\mathrm{Ca}^{2+}$ and biofilm formation in the flasks and a negative correlation between Ca ${ }^{2+}$ and planktonic cells. There was no observable biofilm in control medium while no turbidity was seen at the highest $\mathrm{Ca}^{2+}$ concentration 


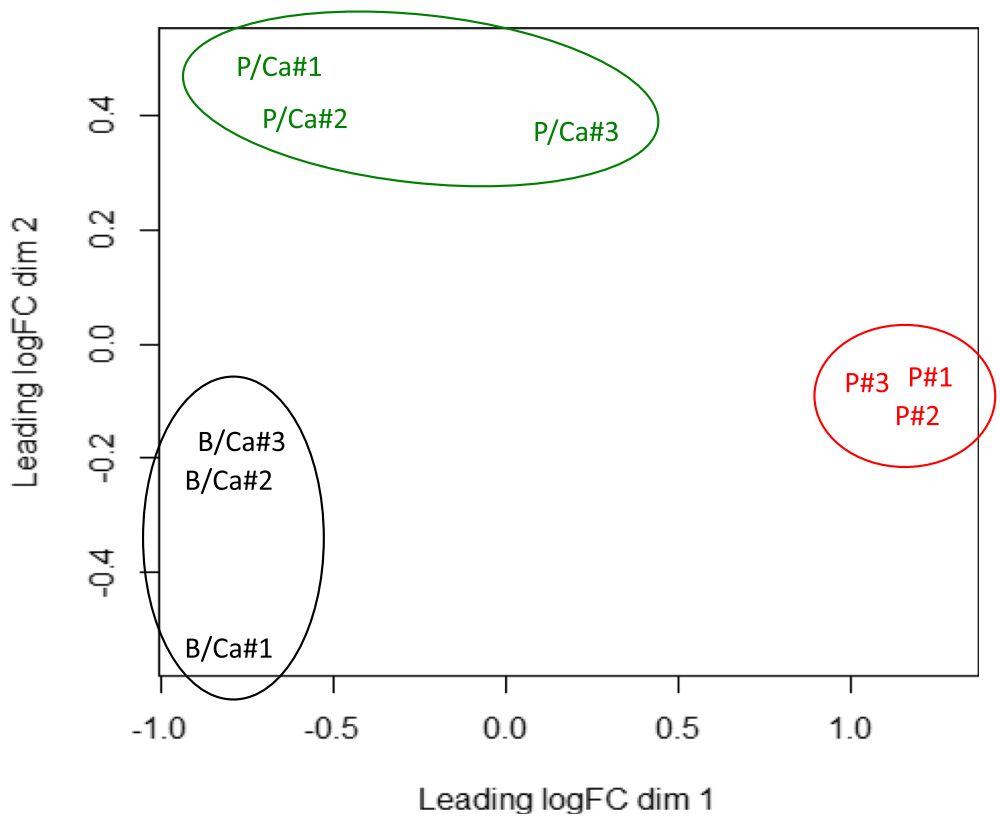

Fig. 2 Principal Component Analysis of biological replicates after mapping to reference sequence Flavobacterium columnare 94-081. P, planktonic samples in control medium; P/Ca, Ca-supplemented medium (4.5 mM); B/Ca, biofilm samples in Ca-supplemented medium (4.5 mM)

and $15.87 \%$ of the total protein-coding genes, respectively. A heatmap of the top 50 differentially expressed genes expression profiles was produced using Blast2Go software v 4.0. Differentially regulated genes were compared among the three treatment groups. Gene expression profiles of $\mathrm{P}$ and $\mathrm{P} / \mathrm{Ca}$ samples were more similar to each other than those exhibited by $\mathrm{B} / \mathrm{Ca}$ samples (Additional file 2: Figure S2).

\section{DEGs identified between biofilm and planktonic cells under equal $\left[\mathrm{Ca}^{2+}\right]$}

One hundred and twelve genes were differentially expressed due to the effect of biofilm as identified between $\mathrm{B} / \mathrm{Ca}$ and $\mathrm{P} / \mathrm{Ca}$ (Fig. 4). The top three upregulated DEGs in biofilm were catalase (WP_060381974; $\log 2 \mathrm{Fc}=2.16$ ), DNA starvation protect protein (WP 060382448; $\log 2 \mathrm{Fc}=2.08$ ), and a hypothetical protein (WP_060382447; $\log 2 \mathrm{FC}=1.75$ ) that contains an EFhand motif with calcium-binding function (Table 1). Other upregulated DEGs in biofilm fell into several functional categories including oxidative stress response, transcriptional regulators, TonB-dependent receptor, and carbohydrate biosynthesis (Table 1 and Additional file 1). In addition, two of upregulated genes in biofilm included a ribosome inactivating protein gene (WP 060383199) that mediates the negative regulation of
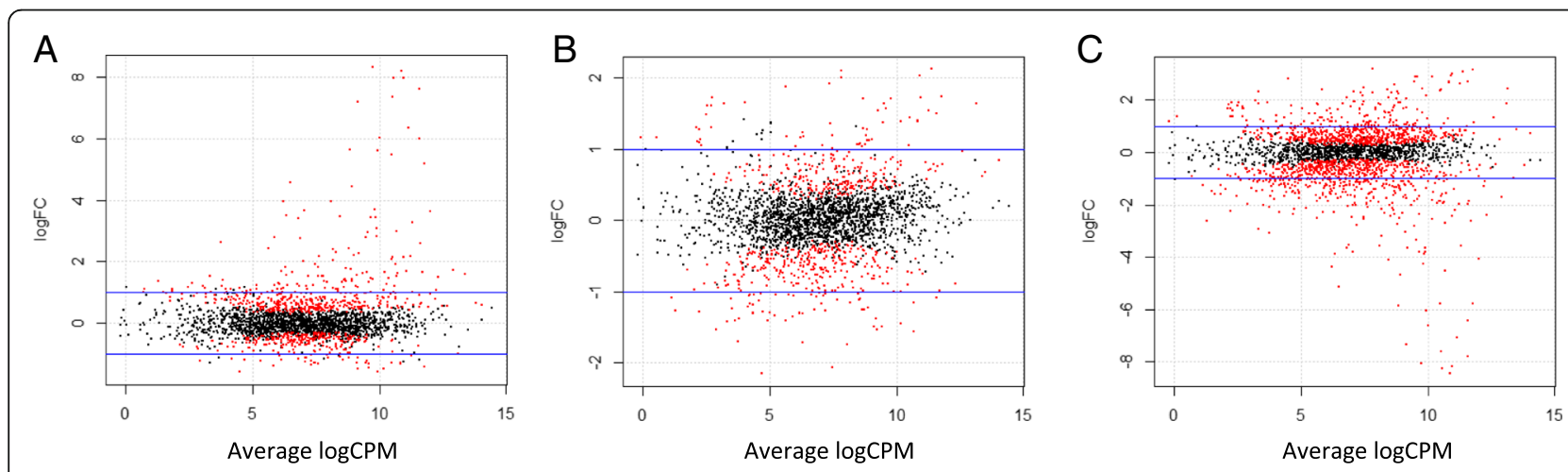

Fig. 3 PlotSmear graph of the samples. Panel a Genes expressed in planktonic cells cultured in Ca-supplemented medium (up) vs planktonic cells cultured in control medium (down). Panel b Genes expressed in planktonic cells cultured in Ca-supplemented medium (up) vs biofilm in Casupplemented medium (down). Panel c Genes expressed in planktonic cells cultured in control medium (up) vs biofilm in Ca-supplemented medium (down). The red dots represent DEGs with $p>0.05$, and the blue lines set threshold with a fold change $>2$ 


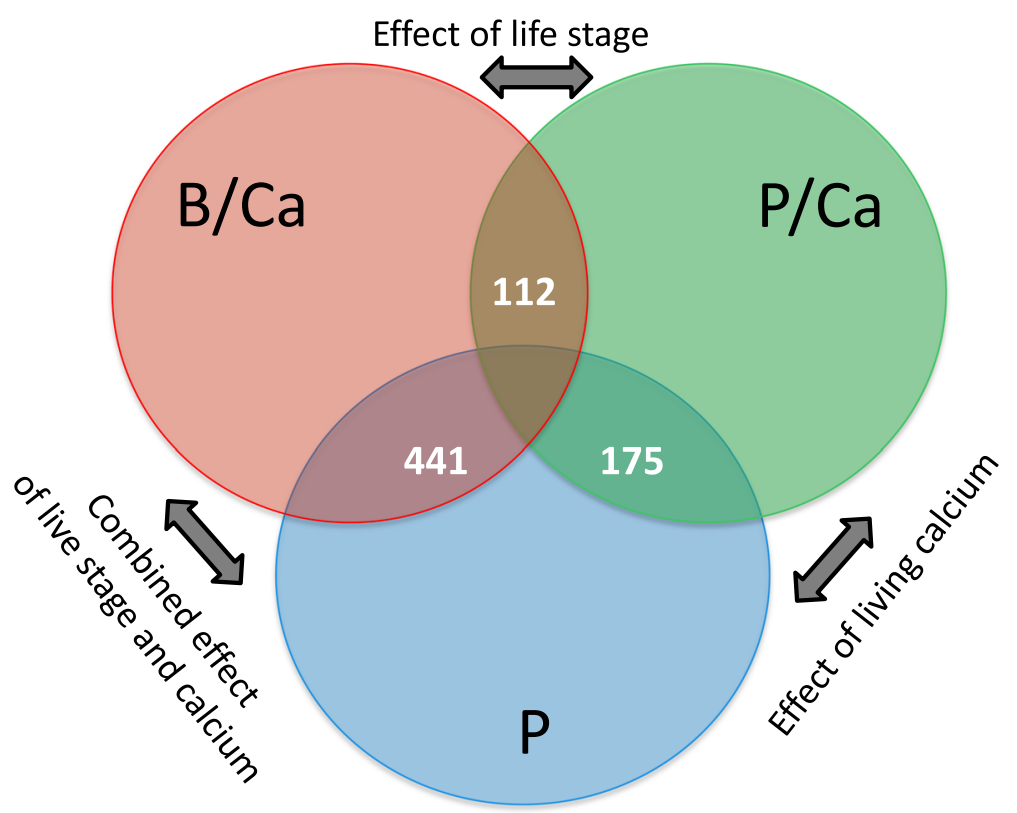

Fig. 4 Venn diagram of the number of significant DEGs among the different biological groups. Three comparison were made: B/Ca:P/Ca; B/Ca:P: P/Ca:P

translation, and an abortive phage infection protein gene (WP_060381920) that leads to programmed death of cells for self-protection [9]. Gene ontology analysis indicated upregulated genes were mostly categorized as integral components of membranes (GO: 0016021; Additional file 1: Figure S3). The top downregulated DGEs in biofilm were associated with aerobic respiration metabolism, type IX secretion system (T9SS) and protein biosynthesis (Table 1).

\section{DEGs between planktonic cells in calcium-supplemented medium and control medium}

There were 175 DEGs between P/Ca and P comparison (Fig. 4). We found more upregulated genes than downregulated genes (135 vs 40) in planktonic cells cultured in calcium-supplemented medium, indicating that $\mathrm{Ca}^{2+}$ activated several metabolic pathways in the cells. Upregulated genes fell into several functional groups including siderophore synthesis, calcium homeostasis, iron acquisition, and genes coding for proteins involved in secretion pathways such as T9SS, flagellar motor protein, and aquaporin (Table 2). On the other side, most of the downregulated genes were associated with aerobic respiration (Additional file 1).

\section{Oxidative stress response in biofilm}

A number of antioxidative genes (e.g. catalase, $A h p C$, cytochrome c peroxide, and thiol reductase thioredoxin) were identified in response to oxidative stress in biofilmassociated growth (Table 1). Catalase (WP_060381974.1; $\log 2 \mathrm{Fc}=2.16)$ was the most upregulated protein-coding gene in biofilm samples when compared to planktonic cells of the same $\left[\mathrm{Ca}^{2+}\right]$. This enzyme breaks down hydrogen peroxide into water and oxygen and its production might increase in response to the elevated reactive oxygen species (ROS) in biofilm. Alkyl hydroperoxide reductase (AhpC; WP_060381975.1; $\log 2 \mathrm{Fc}=$ 1.5 ) is another upregulated antioxidative product in this category, which is the primary scavenger of endogenous hydrogen peroxide in bacterial cells.

\section{Aerobic respiration is greatly limited in biofilm}

Among the top 27 downregulated gene in biofilm, up to 11 genes were associated with cytochrome c respiratory electron transfer (Additional file 1: Table S1), including cytochrome c oxidase (WP_060382480.1), cytochrome c peroxidase (WP_060381419.1), and NADH-ubiquinone reductase (WP_060381562.1). In addition, the gene that codes for the o-succinylbenzoate CoA ligase (WP 060381919.1), an enzyme involved in menaquinone (vitamin $K_{2}$ ) biosynthesis was highly upregulated in biofilm samples. Interestingly, menaquinone is the major electron carrier during anaerobic metabolism and can use various electron acceptors.

\section{Calcium supplementation promotes iron acquisition}

In addition to the cytoplasmic membrane (CM), common to all cells, Gram-negative bacteria possess an outer membrane $(\mathrm{OM})$, which hinders the uptake of essential nutrients. In bacterial cells, iron uptake is conveyed by siderophore transport system. In this study, siderophore biosynthesis protein (WP_060383187.1) was the second 
Table 1 Selected genes in key functional categories differentially expressed in biofilm compared to planktonic cells (both cultured in $\left.4.5 \mathrm{mM}\left[\mathrm{Ca}^{2+}\right]\right)$. Genes were selected based on fold change and their functional relevance

\begin{tabular}{|c|c|c|c|c|}
\hline $\begin{array}{l}\text { Functional } \\
\text { group }\end{array}$ & RefSeq & Product & $\begin{array}{l}\text { Fold change } \\
(\log 2)\end{array}$ & $\begin{array}{l}\text { FDR } \\
\text { (adjusted } p \text { value) }\end{array}$ \\
\hline \multicolumn{5}{|c|}{ EPS/LPS biosynthesis } \\
\hline & WP_060381967.1 & 1,4-polygalactosaminidase & 1.72 & 1.1E-19 \\
\hline & WP_060381836.1 & UDP-N-acetylmuramate--alanine ligase & 1.24 & 4.1E-05 \\
\hline & WP_060381978.1 & SAM-dependent methyltransferase & 1.04 & $3.8 \mathrm{E}-07$ \\
\hline & WP_060382475.1 & Glycosyltransferase & -1.99 & 9.3E-03 \\
\hline \multicolumn{5}{|c|}{ Amino acid metabolism } \\
\hline & WP_060383852.1 & Branched-chain amino acid aminotransferase & -1.53 & $3.52 \mathrm{E}-16$ \\
\hline & WP_060382313.1 & Anthranilate synthase & -1.35 & $2.71 \mathrm{E}-10$ \\
\hline & WP_060382314.1 & Anthranilate phosphoribosyltransferase & -1.03 & $1.18 \mathrm{E}-06$ \\
\hline & WP_060382792.1 & Glycyl aminopeptidase M61 & 1.11 & $2.2 \mathrm{E}-11$ \\
\hline & WP_060382658.1 & Von 25illebrand factore type protein & 1.54 & $5.8 \mathrm{E}-10$ \\
\hline \multicolumn{5}{|l|}{ T9SS } \\
\hline & WP_060383582.1 & T9SS C-terminal target domain-containing protein & -1.53 & $3.52 \mathrm{E}-16$ \\
\hline & WP_060383402.1 & T9SS C-terminal target domain-containing protein & -1.13 & 3.07E-05 \\
\hline \multicolumn{5}{|c|}{ Nutrient limitation } \\
\hline & WP_060381920.1 & Abortive phage infection protein & 1.17 & $5.0 \mathrm{E}-08$ \\
\hline & WP_060383199.1 & Ribosome inactivating protein & 1.30 & $9.27 \mathrm{E}-10$ \\
\hline & WP_060381977.1 & Protein-tryosine-phosphatase & 1.04 & 1.39E-09 \\
\hline & WP_060382448.1 & $\begin{array}{l}\text { DNA starvation protect protein under stressful or poor nutriention } \\
\text { conditions }\end{array}$ & 2.08 & $8.3 \mathrm{E}-23$ \\
\hline \multicolumn{5}{|c|}{ Regulatory functions } \\
\hline & WP_060382614.1 & AraC family transcriptional regulator & 1.71 & $2.9 \mathrm{E}-11$ \\
\hline & WP_060381931.1 & Transcriptional regulator & 1.31 & $5.4 \mathrm{E}-08$ \\
\hline & WP_060381980.1 & ArsR family iron regulation transcriptional regulator & 1.54 & 4.7E-4 \\
\hline \multicolumn{5}{|c|}{ Oxidative stress response } \\
\hline & WP_060381974.1 & Catalase & 2.16 & $8.71 \mathrm{E}-10$ \\
\hline & WP_060381975.1 & Alkyl hydroperoxide reductase & 1.50 & $8.29 \mathrm{E}-15$ \\
\hline & WP_060382235.1 & Cytochrome c peroxidase & 1.41 & $1.31 \mathrm{E}-10$ \\
\hline & WP_014164670.1 & Thiol reductase thioredoxin & 1.03 & 2.35E-09 \\
\hline \multicolumn{5}{|c|}{ Respiratory metabolism } \\
\hline & WP_060381919.1 & O-succinylbenzoic acid CoA ligase & 1.11 & 7.3E-03 \\
\hline & WP_060382480.1 & Cytochrome C oxidase subunit III & -2.12 & 7.45E-06 \\
\hline & WP_060382479.1 & Cytochrome c oxidase accessory protein CcoG & -2.03 & $2.9 \mathrm{E}-06$ \\
\hline & WP_060382481.1 & Cytochrome C oxidase subunit IV & -1.74 & $2.3 \mathrm{E}-05$ \\
\hline & WP_060382478.1 & Cytochrome $\mathrm{C}$ oxidase $\mathrm{Cbb3}$ & -1.74 & $1.94 \mathrm{E}-03$ \\
\hline & WP_060381577.1 & Cytochrome c oxidase subunit I & -1.50 & 1.7E-02 \\
\hline & WP_060381570.1 & Cytochrome C & -1.39 & $3.7 \mathrm{E}-04$ \\
\hline & WP_060381576.1 & Cytochrome C oxidase subunit II & -1.39 & 2.6E-02 \\
\hline & WP_060381561.1 & NADH dehydrogenase & -1.27 & $6.5 \mathrm{E}-03$ \\
\hline & WP_060381560.1 & $\mathrm{NADH}$ oxidoreductase (quinone) subunit F & -1.18 & $6.1 \mathrm{E}-03$ \\
\hline & WP_060381566.1 & $\mathrm{NADH}$-quinone oxidoreductase subunit $\mathrm{L}$ & -1.07 & 1.7E-03 \\
\hline & WP_060381562.1 & NADH:ubiquinone oxidoreductase subunit $\mathrm{H}$ & -1.06 & $1.1 \mathrm{E}-02$ \\
\hline & WP_014164161.1 & $\mathrm{NADH}$-quinone oxidoreductase subunit I & -1.00 & $9.1 \mathrm{E}-03$ \\
\hline
\end{tabular}


Table 2 Selected genes in key functional categories differentially expressed in planktonic cells cultured in $4.5 \mathrm{mM}$ [Ca2+] compared to planktonic cells cultured in control medium

\begin{tabular}{|c|c|c|c|c|}
\hline Functional group & RefSeq & Product & Fold change (log2) & FDR (adjusted $p$ value) \\
\hline \multicolumn{5}{|c|}{ Siderophore synthesis } \\
\hline & WP_060383187.1 & Siderophore alcaligin biosynthesis protein & 8.20 & $4.1 \mathrm{E}-41$ \\
\hline & WP_060383190.1 & LucA/lucC family siderophore biosynthesis protein & 5.64 & $1.7 \mathrm{E}-44$ \\
\hline & WP_060383888.1 & Siderophore biosynthesis protein & 7.21 & $6.4 \mathrm{E}-61$ \\
\hline \multicolumn{5}{|l|}{ Iron transfer } \\
\hline & WP_060383657.1 & Iron transporter & 2.45 & $3.7 \mathrm{E}-13$ \\
\hline & WP_060383656.1 & Ferrous iron transport protein $B$ & 1.53 & $3.2 \mathrm{E}-09$ \\
\hline & WP_060381373.1 & NifU family protein (iron-sulfur cluster binding) & 1.19 & 4.7E-10 \\
\hline \multicolumn{5}{|l|}{ T9SS secretion } \\
\hline & WP_060382679.1 & T9SS C-terminal target domain-containing protein & 7.61 & $8.0 \mathrm{E}-43$ \\
\hline & WP_060383582.1 & T9SS C-terminal target domain-containing protein & 1.58 & $2.8 \mathrm{E}-05$ \\
\hline & WP_060383035.1 & T9SS C-terminal target domain-containing protein & 1.65 & $6.6 \mathrm{E}-10$ \\
\hline \multicolumn{5}{|c|}{ TonB-dependent receptor } \\
\hline & WP_060383861.1 & TonB-dependent receptor & 6.03 & $6.9 \mathrm{E}-40$ \\
\hline & WP_060383182.1 & TonB-dependent receptor & 6.01 & $4.4 \mathrm{E}-49$ \\
\hline & WP_060383101.1 & TonB-dependent receptor & 5.18 & $3.7 E-33$ \\
\hline & WP_060382917.1 & TonB-dependent receptor & -1.22 & $5.7 \mathrm{E}-04$ \\
\hline & WP_060382921.1 & TonB-dependent receptor & -1.59 & 4.4E-02 \\
\hline \multicolumn{5}{|c|}{ Calcium homeostasis } \\
\hline & WP_060383353.1 & $\mathrm{ABC}$ transporter permease & 1.56 & $1.9 \mathrm{E}-11$ \\
\hline & WP_060383434.1 & Outmembrane efflux protein & 1.46 & $2.3 \mathrm{E}-08$ \\
\hline & WP_060383433.1 & Efflux transporter periplasmic adaptor & 1.21 & $1.7 \mathrm{E}-07$ \\
\hline \multicolumn{5}{|c|}{ Integral membrane component } \\
\hline & WP_060381689.1 & Flagellar motor protein MotA & 1.47 & $2.9 \mathrm{E}-06$ \\
\hline & WP_060383854.1 & Aquaporin & 1.69 & $1.9 \mathrm{E}-11$ \\
\hline \multicolumn{5}{|l|}{ Respiration system } \\
\hline & WP_060381562.1 & NADH:ubiquinone oxidoreductase subunit $\mathrm{H}$ & -1.01 & $1.4 \mathrm{E}-02$ \\
\hline & WP_060381556.1 & NADH dehydrogenase & -1.02 & $2.4 \mathrm{E}-03$ \\
\hline & WP_060381560.1 & NADH oxidoreductase (quinone) subunit $F$ & -1.12 & $9.2 \mathrm{E}-03$ \\
\hline & WP_060381555.1 & $\mathrm{NADH}$-quinone oxidoreductase subunit A & -1.12 & $5.3 \mathrm{E}-03$ \\
\hline & WP_060381577.1 & Cytochrome c oxidase subunit I & -1.20 & $5.4 \mathrm{E}-02$ \\
\hline & WP_060381576.1 & Cytochrome C oxidase subunit II & -1.23 & $3.5 \mathrm{E}-02$ \\
\hline & WP_060381574.1 & Cytochrome C & -1.30 & $3.2 \mathrm{E}-02$ \\
\hline & WP_060382919.1 & Cytochrome-c peroxidase & -1.31 & 8.7E-03 \\
\hline & WP_060381571.1 & Quinol:cytochrome C oxidoreductase & -1.41 & $3.2 \mathrm{E}-02$ \\
\hline & WP_060381575.1 & Quinol:cytochrome C oxidoreductase & -1.32 & $2.9 \mathrm{E}-02$ \\
\hline Gliding motility & WP_060383259.1 & Gliding motility protein GldN & -1.01 & $1.5 \mathrm{E}-02$ \\
\hline Quorum sensing & WP_060383185.1 & LuxR family transcriptional regulator & 3.94 & $2.8 \mathrm{E}-29$ \\
\hline
\end{tabular}

$(\log F \mathrm{c}=8.2)$ highest upregulated protein in the planktonic cells under calcium supplementation. We identified a number of protein-coding genes coding for iron acquisition and transport system (Table 2). These include the siderophore biosynthesis, TonB dependent transport system, iron transporter (WP_060383657), ferrous iron transport protein (WP 060383656), and NifU family protein containing iron-sulphur cluster (WP_060381373). There were up to 3 siderophore biosynthesis genes $\left(\log 2 \mathrm{Fc}_{\mathrm{C}}=5.6-8.2\right)$ and 5 TonB 
dependent receptor genes associated with siderophore transportation $(\log 2 \mathrm{Fc}=1.1-6.1)$ were upregulated totally in the calcium-supplemented medium (Table 2).

\section{Calcium supplementation promotes protein secretion by T9SS}

Type IX secretion system (T9SS) is an outer membrane protein secretion system. The common T9SS substrates include proteins involved in gliding and extracellular proteases. Precursor of the T9SS cargo protein contains a conserved C-terminal domain (CTD) during the cargo's translocation across the outer membrane. In our study, multiple genes encoding T9SS C-terminal target domain-containing proteins (WP_060382679.1; WP 0603833582.1; WP_060383035.1; WP_060383402.1) were identified in the upregulated genes in the calciumsupplemented samples (Table 2).

\section{Validation of RNA-seq profiles by qPCR}

In order to validate the differentially expressed genes identified by RNA-seq, 10 genes from various categories were selected for qPCR confirmation. Fold changes from qPCR were compared with the RNA-seq express analysis results. As shown in Fig. 5, qPCR results were significantly correlated with the RNA-seq results (correlation coefficient 0.88 ), indicating a consistency with the transcriptional expression analysis.

\section{Discussion}

Calcium concentration contributes to water quality in the form of water hardness. In general, the effect of calcium to bacterial biofilm formation has been shown to be species-specific. A previous study in our lab showed that the addition of calcium strongly promoted biofilm formation in F. columnare [3]. Similar results have been found in Pseudomonas aeruginosa [10], Sinorhizobium meliloti [11], Xylella fastidiosa [12], Enterobacter cloacae [13], Aeromonas hydrophila [8], and Enterococus faecalis [14]. On the contrary, the addition of calcium suppresses biofilm formation in Vibrio cholerae [15] and Staphylococcus aureus [16].

We have previously established that $F$. columnare, a strictly aerobic bacterium, favors the production of biofilm at the air/liquid interface on glass slides [3] and on other substrates [8] where oxygen is abundant. The consumption of molecular oxygen leads to the accumulation of reactive oxygen species (ROS), potentially leading to oxidative stress [17]. Interestingly, oxidative burst has been proposed as a signal that induces bacteria to form biofilms in order to protect themselves against adverse environmental conditions [18]. In addition, this mechanism seems to be conserved among both Grampositive and Gram-negative bacterial species. For example, $P$. aeruginosa increased the synthesis of the exopolysaccharide (EPS) alginate when it was exposed to hydrogen peroxide [19]. In the presence of oxidative stress, increased production of polysaccharides was

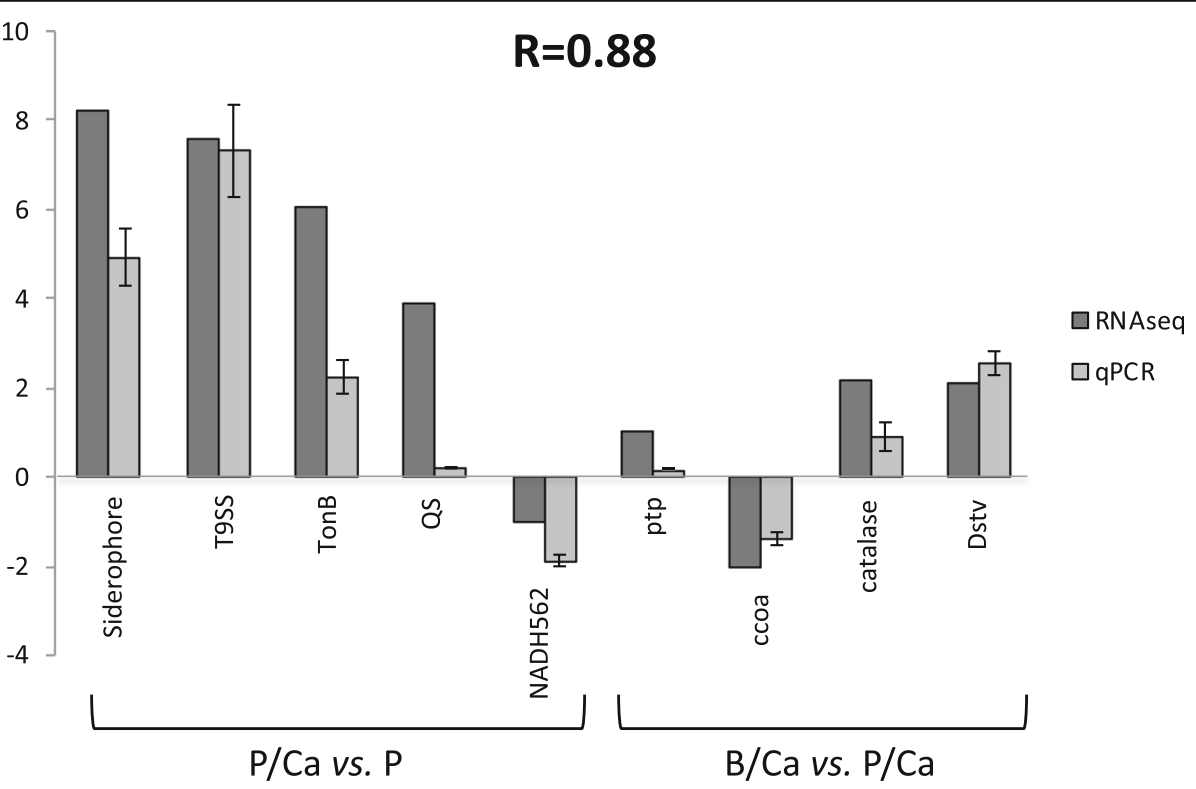

Fig. 5 Comparison of relative fold change between RNA-seq and $\mathrm{APCR}$ results using DEGs in P/Ca and $\mathrm{P}$, and B/Ca and P/Ca. Protein coding sequences abbreviations: Siderophore alcaligin biosynthesis protein (WP_060383187), siderophore; T9SS secretion (WP_060382679), T9SS; Ton-B dependent receptor (WP_060383861), TonB; Quorum sensing (WP_060383185), QS; NADH subunit H (WP_060381562), NADH562; Protein-tyrosinephosphate (WP_060381977), ptp; Cytochrome c oxidase accessory (WP_060382479), ccoa; Catalase (WP_060381974), catalase; DNA starvation protect protein (WP_060382448), Dstv 
observed in Azotobacter vinelandii [20] and Bacillus subtilis [21] biofilm matrices. Although oxidative stress has been broadly observed during biofilm development, it is still unclear whether oxidative stress triggered the biofilm formation or oxidative was the result of metabolism during biofilm development.

In this study, we found that genes involved in aerobic respiration were greatly downregulated in biofilm samples, which indicated a reduced aerobic metabolism in biofilm. Noteworthy was the upregulation of osuccinylbenzoate CoA ligase in biofilm samples, which catalyzes the menaquinone biosynthesis. Menaquinone plays an essential role in several anaerobic electron transport systems as it is the major electron carrier during anaerobic metabolism and can use various electron acceptors [22]. This process of anaerobic respiration allows bacteria to generate the energy required to survive under oxygen-limited conditions. This observation was interesting because $F$. columnare has been regarded as a strictly aerobic bacterium. Although anaerobic respiration in $F$. columnare has not yet been reported, bioinformatics analysis showed that, indeed, the $F$. columnare genome encodes for enzymes that are involved in anaerobic metabolism, such as denitrification that could, theoretically, allow the bacterium to remain metabolically active under anaerobic conditions. This in silico prediction was supported by the fact that high levels of $F$. columnare cells have been detected in anaerobic sediments of catfish ponds by metagenomic analysis [23].

Iron is a co-factor of many enzymes that plays a crucial role in diverse physiological processes such as DNA replication, transcription and central metabolism [24]. Iron is required by virtually all bacterial pathogens and vertebrates, therefore iron acquisition becomes a critical survival strategy during host-pathogen interactions. As a result, bacteria must elaborate Fe-acquisition systems in order to successfully colonize host tissues [25]. Previous studies found that the level of intracellular iron is a signal for the expression of several virulence genes in $F$. psychrophilum [26], and it serves as a signal during biofilm development in P. aeruginosa [27] and S. maltophilia [28]. As the pathogen encounters nutrient deprivation condition during infection, its increased ability to sequester iron is able to enhance bacterial virulence and compromise the host defenses. Pathogenic bacteria encounter iron-limiting conditions in host tissues [28], and, similarly, aquatic bacteria living in biofilms are exposed to low free iron concentrations. It is very intriguing, from an epidemiological point of view, that calcium promoted iron acquisition mechanism in F. columnare which serve as enhanced virulence factors required for host colonization. The phenomena of upregulation of iron-acquisition in biofilm- bound cells has been alsoreported in F. columnare biofilm (Lange et al., 2018) although the expression of siderophore synthesis genes was only found in catfish mucus-stimulated biofilms. The authors have previously suggested that iron acquisition systems were important for biofilm formation (Lange et al., 2017). However, it needs to be noted that in both studies they used a culture medium that contained approximately 100 more $\mathrm{CaCl}_{2}$ than the medium used in our study, therefore it is impossible to discern the role of calcium in upregulating iron-acquisition genes from the role of biofilm. In phylogenetically distantly related bacteria, such as $P$. aeruginosa [29], and Thermotoga maritima [30] calcium has been linked to biofilm formation and upregulation of iron-acquisition genes thus suggesting that the effect of calcium in iron regulation is possibly a conserved mechanism across bacteria.

The type IX secretion system (T9SS) is an outmembrane protein secretion system that is widespread among members of the Phylum Bacteroidetes [31]. T9SS protein substrates have conserved C-terminal domains (CTDs) in common, which function as signaling during cargo transportation. Genetic manipulation of $\operatorname{Rgp} \mathrm{B}$ (a surfaceassociated cysteine proteinase-coding gene) to remove the CTD resulted in the loss of posttranslational modification, surface attachment, and function of the enzyme [32]. In our study, $\mathrm{Ca}^{2+}$ supplementation enhanced the expression of the T9SS C-terminal target domaincontaining proteins in calcium-supplemented samples. The cargo proteins that are transported by the T9SS is poorly characterized in F. columnare but based on their predictive function, we have identified several genes that encode for cargo proteins including a zinc-dependent metalloproteinase (WP_060383035.1). The upregulation of genes that code for T9SS cargo proteins $\mathrm{P} / \mathrm{Ca}$ may partially explain the elevated virulence of $F$. columnare under high hardness (high $\mathrm{Ca}^{2+}$ ) conditions by facilitating extracellular transport of critical proteins involved in attachment and tissue colonization [6]. On the other hand, T9SS-related genes were downregulated in $\mathrm{B} / \mathrm{Ca}$ when compared with $\mathrm{P} / \mathrm{Ca}$ supporting the hypothesis that T9SS plays two roles, depending on the lifestyle of the bacteria (Lasica et al.,): means of movement as part of the gliding machinery in Flavobacterium spp. and secretion of virulence factors involved in attachment and colonization of pathogens. It is not surprising that genes involved in gliding motility are suppressed when cells are in living in biofilm.

\section{Conclusions}

In summary, the transcriptome analysis revealed the specialized biofilm physiology including reduced metabolism and elevated oxidative stress tolerance. Main 
categories of DEGs include genes required for iron uptake, oxidative stress response, respiration pathway, and biosynthesis and secretion of extracellular products. Calcium supplementation promoted the T9SS protein secretion system and iron acquisition, both of which are considered critical virulence factors in the genus Flavobacterium. In addition, the transcriptional response (e.g. oxidative stress, iron acquisition) in biofilm seemed to be a conserved mechanism among even the distantlyrelated bacterial organism. Genetic manipulation of $F$. columnare has proven very difficult and, currently, there are not standard methods available to generate knockout mutants or gene deletions in this species. Future studies are needed to develop a robust set of genetic tools for the manipulation of this pathogen that will allow us to understand the role of some of the genes identified in this study in F. columnare pathogenesis.

\section{Methods}

\section{Bacteria and culture conditions}

Strain ALG-00-530 of $F$. columnare was used in this study. This strain was isolated from channel catfish in Alabama in 2000 [33], and it has been used in previous biofilm studies by our group [3]. Bacterium was stored at $-80^{\circ} \mathrm{C}$ as glycerol stocks and routinely cultured on modified Shieh (MS) agar or broth with shaking (125 $\mathrm{rpm})$ at $28^{\circ} \mathrm{C}$ for $24-48 \mathrm{~h}$ [34]. Calcium concentration in the medium was adjusted to the desired value with $\mathrm{CaCl}_{2} \cdot 2 \mathrm{H}_{2} \mathrm{O}$.

\section{Biofilm formation under different calcium concentrations} Biofilm was assessed in $250 \mathrm{ml}$ Erlenmeyer flasks containing $100 \mathrm{ml}$ of MS broth. Calcium concentration was adjusted to $0,2.5,4.5$ and $6.5 \mathrm{mM}$ with $\mathrm{CaCl}_{2} \cdot 2 \mathrm{H}_{2} \mathrm{O}$. Approximately, $10^{7} \mathrm{CFU} / \mathrm{ml}$ of $F$. columnare ALG-00530 were added to each flask from an overnight culture in MS $(\mathrm{OD}=0.8)$. To allow for air exchange, the mouth of the flasks was covered with autoclaved cotton plugs. Cultures were incubated at $28^{\circ} \mathrm{C}$ for $48 \mathrm{~h}$ under shaking.

\section{RNA extraction}

Biofilm was induced in medium containing $4.5 \mathrm{mM}$ $\left[\mathrm{Ca}^{2+}\right]$ in flasks as described above. Planktonic cells (1 $\mathrm{ml}$ ) from control (no calcium supplementation) and calcium-supplemented media were pelleted by centrifugation at $3000 \mathrm{rpm}$ for $10 \mathrm{~min}$ at $4{ }^{\circ} \mathrm{C}$. Biofilm formed at the interphase between air-liquid, around the edges of the flask. Using a sterilized spatula, approximately $0.05 \mathrm{~g}$ (wet weight) of biofilm was collected from the calciumsupplemented medium. No observable biofilm was produced in control flasks therefore it was not possible to study gene expression in biofilm in the absence of calcium. Planktonic cell pellets and biofilm samples were preserved in RNALater (Qiagen, Valencia, CA) at $4{ }^{\circ} \mathrm{C}$ and frozen at $-20^{\circ} \mathrm{C}$ until processed. RNA was extracted using the TRIzol (Invitrogen, Waltham, MA) method with some modifications required to obtain sufficient RNA from biofilm samples. Briefly, samples were transferred from RNALater into a $2 \mathrm{ml}$ tube (MP Biomedicals, Dayton, $\mathrm{OH}$ ) containing $0.4 \mathrm{~g}$ of acidwashed $500 \mathrm{~mm}$ glass beads and $1 \mathrm{ml}$ TRIzol solution. Samples were vortexed for $40 \mathrm{~s}$ and chilled down on ice for an additional $30 \mathrm{~s}$. This process was repeated three times. Afterwards, $200 \mu \mathrm{l}$ of chloroform was added to each sample and tubes were centrifuged at $12,000 \mathrm{~g}$ for $15 \mathrm{~min}$ at $4{ }^{\circ} \mathrm{C}$. The supernatant was transferred to a new tube and washed again with equal volume of chloroform/isoamyl alcohol (24:1) solution. The aqueous phase was then carefully transferred to a new tube and mixed with equal volume of $100 \%$ ethanol. RNA was precipitated at $-20{ }^{\circ} \mathrm{C}$ for at least $30 \mathrm{~min}$ and washed twice in $75 \%$ ethanol before resuspended it into $60 \mu \mathrm{l}$ of DEPC-water. RNA concentration and purity was spectrometrically determined using a NanoDrop 1000 (Thermo Scientific, Waltham, MA). RNA concentration and integrity were further assessed with a 2100 Bioanalyzer (Agilent Technologies, Santa Clara, CA) before proceeding to RNA sequencing. Three independent replicates were carried out per sample type.

\section{RNA sequencing}

RNA-Seq library preparation was carried out by HudsonAlpha Genomic Service Lab (Huntsville, AL, USA). RNA integrity numbers (RIN) of the 9 samples were between 7.8-9.8 (average 9.2). Ribosomal RNA was removed from each sample using the RiboZero Gold Epidemiology rRNA Removal kit (Illumina, San Diego, CA). cDNA libraries were prepared through the NEBNext Ultra II synthesis module workflow (New England BioLabs, Ipswich, MA). The libraries were pooled and sequenced with $2 \times 100 \mathrm{bp}$ paired-end reads on an Illumina HiSeq2000 instrument.

\section{RNA-Seq data analysis}

Adapter removal and quality trimming of FASTQ files was conducted using Trimmomatic [35] by the HudsonAlpha Genomic Service Lab. Data quality was assessed using FastQC version 0.10.1 (Babraham Bioinformatics). Reads were aligned to $F$. columnare strain 94-081 [36] protein-coding sequences (Accession number NZ_CP013992) using the Bowtie2 software [37]. The alignment statistics were obtained using Samtools [38]. Differentially expressed genes were identified using EdgeR [39]. Genes with an FDR-adjusted $p$ value $<0.05$, and fold change $>2$ were identified as being differentially expressed. Functional annotation and gene ontology were also conducted using BLAST2Go PRO software [40]. 
Gene descriptions were annotated as in GeneBank of NCBI. When appropriate, gene annotations were updated with information from InterPro protein database by InterProScan 5 [41] for predicted functional domains.

\section{qPCR validation and statistical analysis}

Nine genes that were up- or down-regulated by more than twofold were selected for qPCR validation of RNA-Seq data. Five genes were identified in the comparison $\mathrm{P} / \mathrm{Ca}$ versus $\mathrm{P}$ and 4 genes were selected from the comparison $\mathrm{B} / \mathrm{Ca}$ versus $\mathrm{P} / \mathrm{Ca}$. Genes were selected based on their functional annotations and were involved in iron acquisition, quorum sensing, and protein secretion. The primer pairs used in this study are listed in Additional file 2: Table S1. Total RNA (subsample from DNase-treated RNA samples that were used for sequencing) was reverse transcribed into cDNA with Applied Biosystems Reverse Transcription kit (Life Technologies Corporation, CA) according to the manufacture's protocol. QPCR was carried out using Applied Biosystems 7500 Real-time PCR system with the following cycle conditions: $95^{\circ} \mathrm{C}$ for $10 \mathrm{~min}$, followed by 40 cycles of $95^{\circ} \mathrm{C}$ for $15 \mathrm{~s}$, and $60{ }^{\circ} \mathrm{C}$ for $60 \mathrm{~s}$. Three biological replicates were used for RNA-seq treatments and subsequent qPCR validation. QPCR results were statistically analyzed using SAS software version 9.2 (SAS Institute, Cary, $\mathrm{NC}$ ). The significant difference was set at $p \leq 0.05$.

\section{Additional files}

Additional file 1: Additional material includes three lists with differentially expressed genes (all data shown: RPM $>1, F D R<0.05$, and fold change $>$ 2.0.). Supplemental Table 1. DEGs between $F$. columnare ALG-00-530 bacterial cells in biofilm compared to planktonic cells in 4.5 mM [Ca2+]. Supplemental Table 2. DEGs between F. columnare ALG-00530 planktonic cells in planktonic cells in $4.5 \mathrm{mM}[\mathrm{Ca} 2+]$ compared to planktonic cells in control medium. Supplemental Table 3. DEGs between F. columnare ALG-00-530 biofilm cells in $4.5 \mathrm{mM}$ [Ca2+] medium compared to planktonic cells in control medium. (DOCX $95 \mathrm{~kb}$ )

Additional file 2: Supplemental Table 4. Primers used for $q P C R$. Figure S1. Library size for all samples. Figure S2. Heat-map of the top50 DEGs expression profiles among the 9 samples after $48 \mathrm{~h}$ incubation. Figure S3. Gene ontology annotation of the up- (panel A) and downregulated (panel B) genes between samples. (DOCX $992 \mathrm{~kb}$ )

\section{Abbreviations}

B: Biofilm cells; Ca: Cells in calcium-enriched medium; Ca2 + : Calcium; CM: Cytoplasmic membrane; CTD: C-terminal domain; DEGs: Differentially expressed genes; DNA: Deoxyribonucleic acid; OM: Outer membrane; P: Planktonic cells; PCA: Principal component analysis; QPCR: Quantitative polymerase chain reaction; RNA: Ribonucleic acid; ROS: Reactive oxygen species; USDA: United States Department of Agriculture

\section{Acknowledgments}

We thank Hongyu Chen (Auburn University) for technical assistance during RNA extractions.

\section{Authors' contributions}

WC carried out the experimental plan, collected samples, extracted RNA and conducted data analysis. He participated in the experimental design, and drafted the manuscript. LDF participated in drafting the objectives and hypothesis, helped with experimental design and data analysis, and contributed to manuscript revision. CA contributed to project design, original objectives and data analysis and revised manuscript. All authors read and approved the final manuscript.

\section{Funding}

The project was funded by the Southeastern Cooperative Fish Parasite and Disease Project (C. Arias, PI) and the Auburn University Intramural Grant Program (De La Fuente, Pl; C. Arias, Co-PI), and the Alabama Experiment Station through USDA-HATCH funds.

\section{Availability of data and materials}

The datasets generated and analyzed during the current study are available from the corresponding author on reasonable request.

Ethics approval and consent to participate

Not applicable.

\section{Consent for publication}

Not applicable.

\section{Competing interests}

The authors declare that they have no competing interests.

\section{Author details}

${ }^{1}$ School of Fisheries, Aquaculture, and Aquatic Sciences, Auburn University, 203 Swingle Hall, Auburn, AL 36849, USA. ²Department of Entomology and Plant Pathology, Auburn University, Auburn, AL, USA.

Received: 11 February 2019 Accepted: 27 June 2019

Published online: 04 July 2019

References

1. Austin B, Austin DA. Bacterial fish pathogens: disease of farmed and wild fish. Chichester: Praxis Publishing Ltd; 2007.

2. Welker TL, Shoemaker CA, Arias CR, Klesius PH. Transmission and detection of Flavobacterium columnare in channel catfish Ictalurus punctatus. Dis Aquat Org. 2005;63(2):129-38.

3. Cai W, De La Fuente L, Arias CR. Biofilm formation by the fish pathogen Flavobacterium columnare: development and parameters affecting surface attachment. Appl Environ Microbiol. 2013;79(18):5633-42.

4. Branda SS, Vik $\AA$, Friedman L, Kolter R. Biofilms: the matrix revisited. Trends Microbiol. 2005;13(1):20-6.

5. Matin A, Khan Z, Zaidi S, Boyce M. Biofouling in reverse osmosis membranes for seawater desalination: phenomena and prevention. Desalination. 2011;281:1-16. https://doi.org/10.1016/j.desal.2011.06.063

6. Straus DL, Farmer BD, Beck BH, Bosworth BG, Torrans EL, Tucker CS. Water hardness influences Flavobacterium columnare pathogenesis in channel catfish. Aquaculture. 2015:435:252-6.

7. Bullard SA, McElwain A, Arias CR. Scanning Electron microscopy of "saddleback" lesions associated with experimental infections of Flavobacterium columnare in channel catfish, Ictalurus punctatus (Siluriformes: Ictaluridae), and zebrafish, Danio rerio (Cypriniformes: Cyprinidae). J World Aquacult Soc. 2011;42(6):906-13.

8. Cai W, Arias CR. Biofilm formation on aquaculture substrates by selected bacterial fish pathogens. J Aquat Anim Health. 2017;29(2):95-104.

9. Dy RL, Przybilski R, Semeijn K, Salmond GP, Fineran PC. A widespread bacteriophage abortive infection system functions through a type IV toxin-antitoxin mechanism. Nucleic Acids Res. 2014;42(7):4590-605.

10. Sarkisova S, Patrauchan MA, Berglund D, Nivens DE, Franklin MJ. Calcium-induced virulence factors associated with the extracellular matrix of mucoid Pseudomonas aeruginosa biofilms. J Bacteriol. 2005;187(13):4327-37.

11. Rinaudi L, Fujishige NA, Hirsch AM, Banchio E, Zorreguieta A, Giordano W. Effects of nutritional and environmental conditions on Sinorhizobium meliloti biofilm formation. Res Microbiol. 2006;157(9):867-75. 
12. Cruz LF, Cobine PA, De La Fuente L. Calcium increases Xylella fastidiosa surface attachment, biofilm formation, and twitching motility. Appl Environ Microbiol. 2012;78(5):1321-31.

13. Zhou G, Li L-j, Q-s S, Y-s O, Y-b C, W-f H. Efficacy of metal ions and isothiazolones in inhibiting Enterobacter cloacae BF-17 biofilm formation. Can J Microbiol. 2013;60(1):5-14.

14. Das T, Sehar S, Koop L, Wong YK, Ahmed S, Siddiqui KS, Manefield M. Influence of calcium in extracellular DNA mediated bacterial aggregation and biofilm formation. PLoS One. 2014;9(3):e91935.

15. Bilecen $\mathrm{K}$, Yildiz FH. Identification of a calcium controlled negative regulatory system affecting Vibrio cholerae biofilm formation. Environ Microbiol. 2009;11(8):2015-29.

16. Shukla SK, Rao TS. Dispersal of bap-mediated Staphylococcus aureus biofilm by proteinase K. J Antibiot. 2013;66(2):55.

17. Gambino M, Cappitelli F. Mini-review: biofilm responses to oxidative stress. Biofouling. 2016;32(2):167-78.

18. Karatan E, Watnick P. Signals, regulatory networks, and materials that build and break bacterial biofilms. Microbiol Mol Biol Rev. 2009;73(2):310-47.

19. Mathee K, Ciofu O, Sternberg C, Lindum PW, Campbell Jl, Jensen P, Johnsen AH, Givskov M, Ohman DE, Søren M. Mucoid conversion of Pseudomonas aeruginos by hydrogen peroxide: a mechanism for virulence activation in the cystic fibrosis lung. Microbiology. 1999;145(6):1349-57.

20. Villa F, Remelli W, Forlani F, Gambino M, Landini P, Cappitelli F. Effects of chronic sub-lethal oxidative stress on biofilm formation by Azotobacter vinelandii. Biofouling. 2012;28(8):823-33.

21. Gambino M, Marzano V, Villa F, Vitali A, Vannini C, Landini P, Cappitelli F. Effects of sublethal doses of silver nanoparticles on Bacillus subtilis planktonic and sessile cells. J Appl Microbiol. 2015;118(5):1103-15.

22. Daruwala R, Bhattacharyya DK, Kwon O, Meganathan R. Menaquinone (vitamin K2) biosynthesis: overexpression, purification, and characterization of a new isochorismate synthase from Escherichia coli. J Bacteriol. 1997; 179(10):3133-8

23. Nho SW, Abdelhamed H, Akgul A, Karsi A, Lawrence ML. Denitrification and anaerobic growth in Flavobacterium columnare. In: 4th international conference on members of the genus Flavobacterium: October 27-29 2015. Auburn: Auburn University; 2015.

24. Andreini C, Bertini I, Cavallaro G, Holliday GL, Thornton JM. Metal ions in biological catalysis: from enzyme databases to general principles. JBIC J Biol Inorg Chem. 2008;13(8):1205-18.

25. Hood MI, Skaar EP. Nutritional immunity: transition metals at the pathogen-host interface. Nat Rev Microbiol. 2012;10(8):525.

26. Møller JD, Ellis A, Barnes A, Dalsgaard I. Iron acquisition mechanisms of Flavobacterium psychrophilum. J Fish Dis. 2005;28(7):391-8.

27. Banin E, Vasil ML, Greenberg EP. Iron and Pseudomonas aeruginosa biofilm formation. Proc Natl Acad Sci U S A. 2005;102(31):11076-81.

28. García CA, Alcaraz ES, Franco MA, de Rossi BNP. Iron is a signal for Stenotrophomonas maltophilia biofilm formation, oxidative stress response, OMPs expression, and virulence. Front Microbiol. 2015;6:926. https://doi.org/ 10.3389/fmicb.2015.00926. eCollection 2015.

29. Patrauchan MA, Sarkisova SA, Franklin MJ. Strain-specific proteome responses of Pseudomonas aeruginosa to biofilm-associated growth and to calcium. Microbiology. 2007;153(11):3838-51.

30. Pysz MA, Conners SB, Montero Cl, Shockley KR, Johnson MR, Ward DE, Kelly RM. Transcriptional analysis of biofilm formation processes in the anaerobic, hyperthermophilic bacterium Thermotoga maritima. Appl Environ Microbiol. 2004;70(10):6098-112.

31. McBride MJ, Zhu Y. Gliding motility and Por secretion system genes are widespread among members of the phylum Bacteroidetes. J Bacteriol. 2013;195(2):270-8

32. Veith PD, Nor Muhammad NA, Dashper SG, Likic VA, Gorasia DG, Chen D, Byrne SJ, Catmull DV, Reynolds EC. Protein substrates of a novel secretion system are numerous in the Bacteroidetes phylum and have in common a cleavable C-terminal secretion signal, extensive post-translational modification, and cell-surface attachment. J Proteome Res. 2013;12(10):4449-61

33. Arias CR, LaFrentz S, Cai W, Olivares-Fuster O. Adaptive response to starvation in the fish pathogen Flavobacterium columnare: cell viability and ultrastructural changes. BMC Microbiol. 2012;12(1):1.

34. Shoemaker CA, Arias CR, Klesius PH, Welker TL. Technique for identifying Flavobacterium columnare using whole cell fatty acid profiles.

J Aquat Anim Health. 2005;17(3):267-74.
35. Bolger AM, Lohse M, Usadel B. Trimmomatic: a flexible trimmer for Illumina sequence data. Bioinformatics. 2014;30:2114-20 btu170.

36. Kumru S, Tekedar HC, Waldbieser GC, Karsi A, Lawrence ML. Genome sequence of the fish pathogen Flavobacterium columnare genomovar II strain 94-081. Genome Announc. 2016;4(3):e00430-16.

37. Langmead B, Salzberg SL. Fast gapped-read alignment with bowtie 2. Nat Methods. 2012;9(4):357-9.

38. Li H, Handsaker B, Wysoker A, Fennell T, Ruan J, Homer N, Marth G, Abecasis $\mathrm{G}$, Durbin R. The sequence alignment/map format and SAMtools. Bioinformatics. 2009;25(16):2078-9.

39. Robinson MD, McCarthy DJ, Smyth GK. edgeR: a Bioconductor package for differential expression analysis of digital gene expression data. Bioinformatics. 2010;26(1):139-40.

40. Conesa A, Götz S, García-Gómez JM, Terol J, Talón M, Robles M. Blast2GO: a universal tool for annotation, visualization and analysis in functional genomics research. Bioinformatics. 2005;21(18):3674-6.

41. Jones $P$, Binns $D$, Chang H-Y, Fraser M, Li W, McAnulla C, McWilliam H, Maslen J, Mitchell A, Nuka G. InterProScan 5: genome-scale protein function classification. Bioinformatics. 2014;30(9):1236-40.

\section{Publisher's Note}

Springer Nature remains neutral with regard to jurisdictional claims in published maps and institutional affiliations.
Ready to submit your research? Choose BMC and benefit from:

- fast, convenient online submission

- thorough peer review by experienced researchers in your field

- rapid publication on acceptance

- support for research data, including large and complex data types

- gold Open Access which fosters wider collaboration and increased citations

- maximum visibility for your research: over $100 \mathrm{M}$ website views per year

At $\mathrm{BMC}$, research is always in progress.

Learn more biomedcentral.com/submissions 